\title{
A compact EES program to predict the axial temperature field in triple-fluid heat exchanger
}

\author{
Nguyen Minh Phu ${ }^{1,2}{ }^{*}$
}

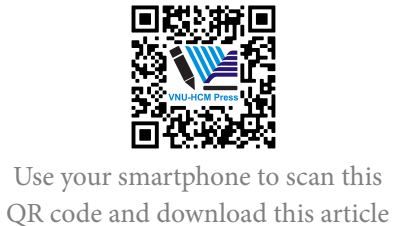

${ }^{1}$ Faculty of Mechanical Engineering, Ho Chi Minh City University of Technology, Viet Nam

\begin{abstract}
In this paper, a simplified mathematical model is presented to predict the axial temperature field of fluids in a three-concentric tube heat exchanger. The model is formed on the basis of heat balance equation, heat transfer equation, temperature gradients, and the logarithmic mean temperature difference (LMTD) method. The triple tube heat exchanger is an alternative solution in order to enhance heat transfer and reduce working fluid pressure loss. The control volume method was adopted to determine axial temperature field by using the computer software Engineering Equation Solver (EES). The combination of the method and EES proves a fast convergence and remarkably small error. The EES code consists of about twenty lines which demonstrates simplicity and compactness of the developed program. Calculation results are compared with experimental results to confirm accuracy. The objective of the study is to avoid temperature cross which is very likely to be occurred in triple-fluid heat exchangers. The temperature cross or temperature meet results in the ineffective surface area in a heat exchanger. Thereby the designer or operator can adjust the design parameters, e.g. geometric parameters of the exchanger, temperatures or fluid flow rates, so that the temperature cross does not occur. The result of calculating a case shows that at the tube length of $21.5 \mathrm{~m}$, the temperature cross occurs between the hot fluid and the intermediate fluid at a certain position. The shorten tube length to $8.5 \mathrm{~m}$ yields desirable gain. EES code and calculation procedure in detail are presented in the current study. The present study is capable to apply various types of heat transfer surface, i.e. finned or ribbed surfaces, and fluids, i.e. gas, liquid, or mixture. Moreover, optimization in terms of thermohydraulic performance could be expanded for the triple fluid heat exchanger.
\end{abstract}

Key words: Temperature cross, Triple-tube, Triple-fluid, Temperature distribution, EES, Heat exchanger

\section{INTRODUCTION}

Correspondence

Nguyen Minh Phu, Faculty of Mechanical Engineering, Ho Chi Minh City University of Technology, Viet Nam

Viet Nam National University Ho Chi Minh City, Viet Nam

Email: nmphu@hcmut.edu.vn

History

- Received: 17-04-2020

- Accepted: 26-10-2020

- Published: 03-11-2020

DOI : 10.32508/stdjet.v3i3.736

\section{Check for updates}

\section{Copyright}

(c) VNU-HCM Press. This is an openaccess article distributed under the terms of the Creative Commons Attribution 4.0 International license.

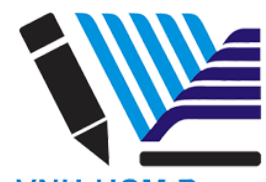

VNU-HCM Press
Heat exchangers are vital components of the thermal system. Their performance determines the cost of investment and operation of the system. Therefore, performance improvement of the exchangers is always paid attention by researchers. It could be helically coiled tube usage for higher heat transfer than straight tube $^{1}$ or application of finned tubes to enhance heat and mass transfer in dehumidifying air coils ${ }^{2}$ or utilization of high performance tube to enhance boiling and condensing heat transfer in a water chiller ${ }^{3}$, or introduction of roughness elements to discard the viscous sublayer and create a mix of the primary flow and secondary flow in a fluid channel ${ }^{4,5}$. In recent years, triple-fluid heat exchanger (TFHE) has been widely employed due to high heat exchange capacity and reduced pressure loss compared to dual-fluid heat exchangers ${ }^{6,7}$. However, there is a disadvantage of the TFHE which may be a phenomenon of temperature cross or meet inside the device. If cold fluid temperature is greater than hot fluid temperature, the phenomenon is referred to as the temperature cross. Temperature cross is undesirable for a heat exchanger because the heat transfer surface area is not utilized effectively ${ }^{8}$. Mohapatra et al. ${ }^{6}$ pointed out the temperature cross in TFHE for various flow patterns. To search for temperature cross, it is necessary to know the temperature distribution of fluid in the device. This distribution is usually determined through analytical approach, numerical simulation (CFD), or experiment. Batmaz and Sandeep ${ }^{9,10}$ studied analytically and experimentally to determine the temperature distribution. A mathematical model of 68 equations was formed and an iterative method is required to solve the model. Mohapatra et al. ${ }^{6}$ applied control volume approach to compute the temperature of three fluids. Gomaa et al. ${ }^{11}$ presented the temperature distributions using numerical (CFD) and experimental studies.

From the above analysis of the role of triple-fluid heat exchangers, the physical significance of temperature cross and approaches in literature, in this study, 
a one-dimensional mathematical model was established for triple-fluid heat exchanger using concentric tubes. The model is based on the fluid temperature gradient and is solved with the support of EES software $^{12}$. This software is a compact tool integrated in many technical books so the EES program is easy to use and develop further.

\section{MODEL DESCRIPTION AND MATHEMATICAL FORMULATION}

The TFHE includes three concentric tubes, as seen in Figure 1. The counterflow configuration is selected due to its larger effectiveness compared to co-current flow and others ${ }^{11}$. Fluid 2 has a higher temperature than that of fluids 1 and 3 . Therefore, the fluid 2 transfers thermal energy via surfaces of innermost tube and intermediate tube. The heat transfer rate of the fluids in the innermost tube and the annuli for one-phase heat transfer are estimated via the following equations ${ }^{7}$ :

$$
\begin{aligned}
& \dot{Q}_{1}=c_{p, 1} \dot{m}_{1}\left(T_{1, o}-T_{1, i}\right) \\
& \dot{Q}_{2}=c_{p, 2} \dot{m}_{2}\left(T_{2, o}-T_{2, i}\right) \\
& \dot{Q}_{3}=c_{p, 3} \dot{m}_{3}\left(T_{3, o}-T_{3, i}\right)
\end{aligned}
$$

where $\stackrel{*}{m}$ is the mass flow rate of a fluid. The subscripts 1,2 , and 3 denote fluids in the innermost tube, inner and outer annuli, respectively. The heat transferred from the highest temperature fluid is the entire thermal duty of the TFHE:

$$
\dot{Q}_{2}=\dot{Q}_{1}+\dot{Q}_{3}
$$

The axial temperature variation of fluids can be predicted from the temperature change along the length of TFHE as:

$$
\begin{gathered}
\frac{d T_{1}}{d x}=(U A)_{21} \frac{T_{2}-T_{1}}{L \dot{m}_{1} c_{p, 1}}, \\
\frac{d T_{2}}{d x}= \\
-(U A)_{21} \frac{T_{2}-T_{1}}{L \dot{m}_{2} c_{p, 2}}-(U A)_{23} \frac{T_{2}-T_{3}}{L \dot{m}_{2} c_{p, 2}}, \\
\frac{d T_{3}}{d x}=(U A)_{23} \frac{T_{2}-T_{3}}{L \dot{m}_{3} c_{p, 3}},
\end{gathered}
$$

where $x$ is the axial position of the TFHE, $L$ is the tube length of the TFHE and $U A$ is the product of overall heat transfer coefficient and heat transfer area. The
$U A$ between the fluids in innermost tube and inner annulus can be computed as:

$$
(U A)_{21}=\frac{1}{\frac{1}{h_{1} A_{1}}+\frac{\ln \left(d_{1, o} / d_{1, i}\right)}{2 \pi k_{\text {tube }} L}+\frac{1}{h_{2} A_{2}}}
$$

Similarly, the conductance between the fluid 2 and fluid 3 in the outer annulus is given as:

$$
(U A)_{23}=\frac{1}{\frac{1}{h_{2} A_{3}}+\frac{\ln \left(d_{2, o} / d_{2, i}\right)}{2 \pi k_{\text {tube }} L}+\frac{1}{h_{3} A_{4}}},
$$

where $k_{t u b e}$ is the thermal conductivity of tubing material and $A$ is the heat transfer surface area:

$$
\begin{aligned}
& A_{1}=\pi d_{1, i} L \\
& A_{2}=\pi d_{1, o} L \\
& A_{3}=\pi d_{2, i} L \\
& A_{4}=\pi d_{2, o} L
\end{aligned}
$$

\section{CONTROL VOLUME METHOD}

The heat exchanger is divided into several elements (Control Volume - CV) to solve the temperature gradient equations. Each $\mathrm{CV}$ has three inlets and three outlets as shown in Figure 2. In this study, exchanger geometry, fluid inlet temperatures and flow rates are given. Fluid temperature distributions are calculated and outlet temperatures as well. From the gradient temperature equations and flow pattern in Figure 1, it can be seen that known temperature of fluids 1 and 3 on the left side, and known temperature of fluid 2 on the right side. The algorithm-solving strategy in the appendix goes from right to left, so that the outlet temperature of fluids 1 and 3 are assumed (red font in the appendix). The inlet temperature of fluids 1 and 3 is calculated and compared with the given data until the smallest error obtained ${ }^{13,14}$. The following shows the calculation procedure with the above mathematical model and manipulation in EES.

Step 1: Write EES code as appendix

Step 2: Select $\mathrm{min} / \mathrm{max}$ calculation as seen in Figure 3

Step 3: Assign minimization of err function and two independent variables (Figure 4a), click on Bounds button to specify range of the variables as showed in Figure 4b. Optimization result displayed in Figure 4c revealed the very small error after 259 iterations and outlet temperature of fluids 1 and 3.

Step 4: Show numeric results of fluid temperature distribution in Integral Tables (Figure 5) 

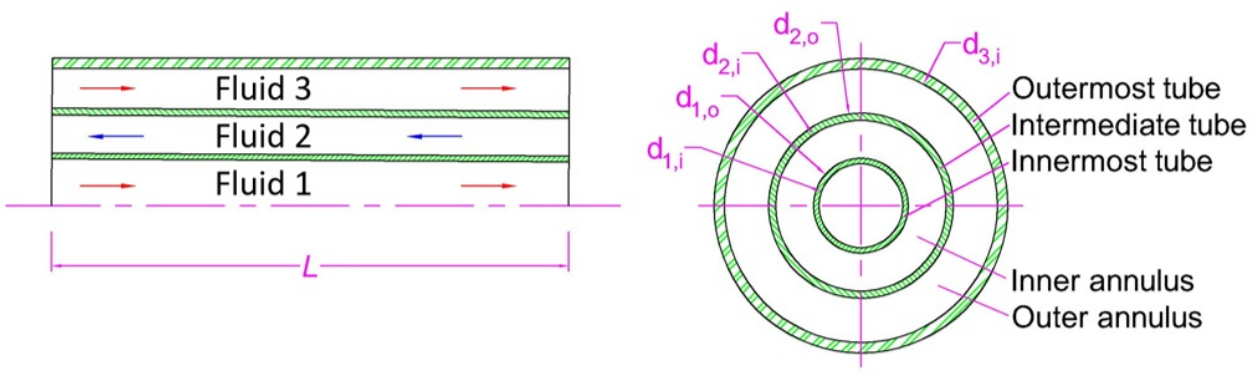

Figure 1: Flow configuration and terminologies for the triple-fluid heat exchanger (TFHE)

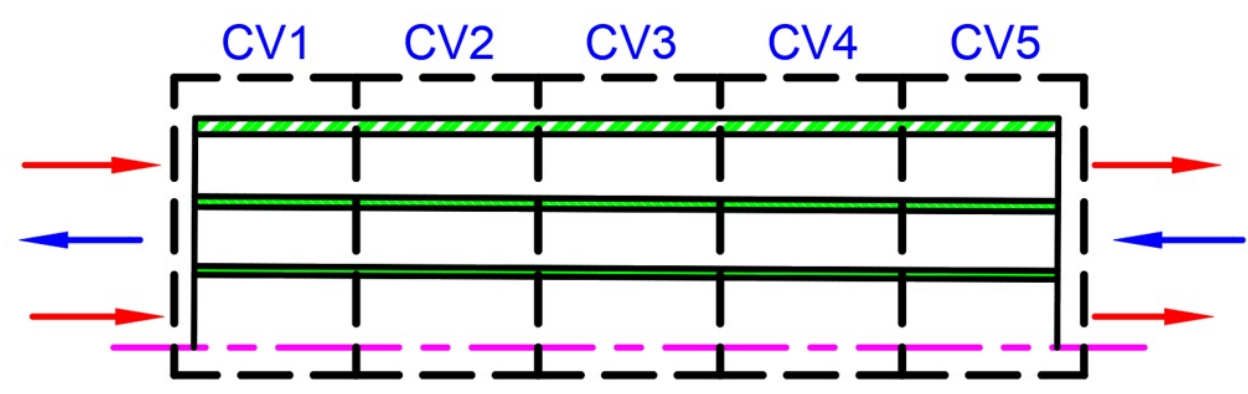

Figure 2: Control volume arrangement

EEy EES Professional: E:IPhu HP split 07.10.2018\De tai Triple concentric-tube heat exchange

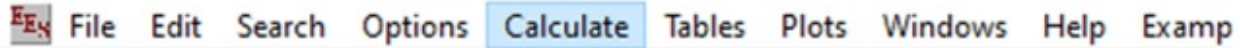

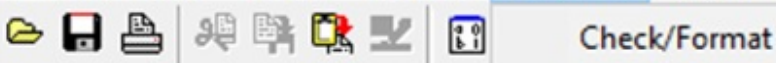
\$UnitSystem SI Pa J C D_1_i $=$ D_1_o-2*th D_1_o $=0.0508[\mathrm{~m}]$ D_2_i $=$ D_2_o- $2^{*}$ th D_2_o $=0.0635[\mathrm{~m}]$ D_3_i =D_3_o-2*th D_3_o $=0.0762[\mathrm{~m}]$ th $=0.00165[\mathrm{~m}]$

Solve $\mathrm{Ctrl}+\mathrm{K}$ E<smiles>[C]1[CH]CCC1</smiles>
.......... F3 Min/Max $\mathrm{F} 4$ Min/M̈ä Table

Uncertainty Propagation F6 Uncertainty Propagation Table

Check Units

Update Guesses

Ctrl+G

Reset Guesses

Figure 3: Min/Max calculation in EES 

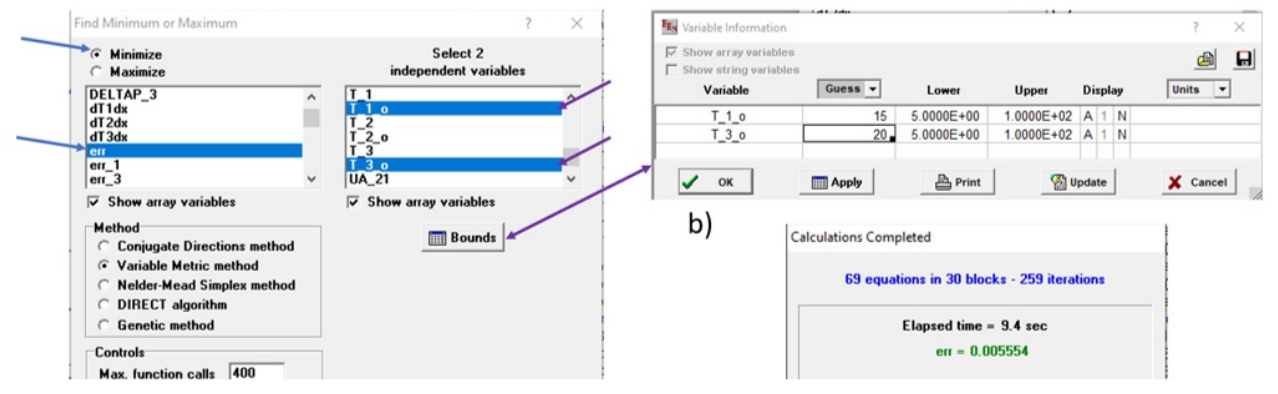

Figure 4: Setups to minimize error

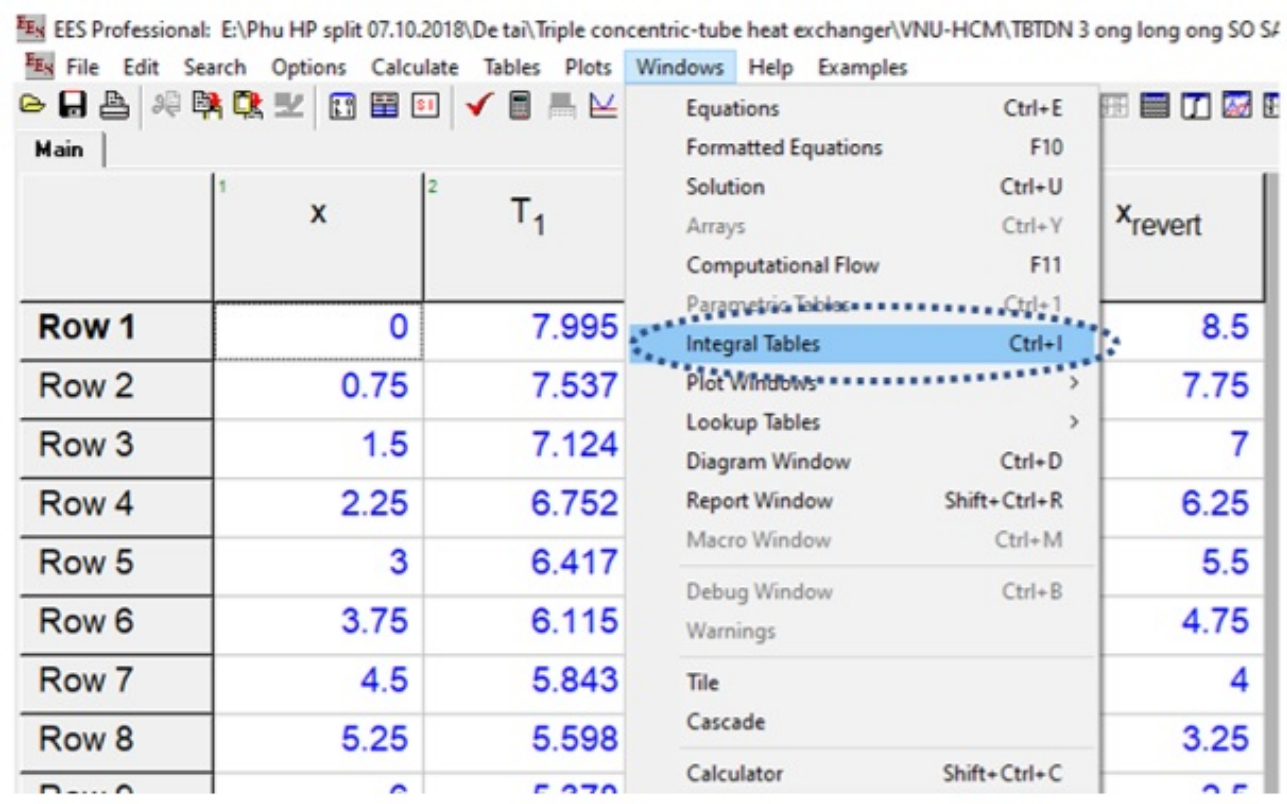

Figure 5: Axial fluid temperature distribution from integral tables

\section{RESULTS AND DISCUSSION}

Figure 6 exhibits a validation of the present results with the experimental outcomes in the literature ${ }^{9}$. The input data, i.e., the fluid types, volumetric flow rate, temperatures of fluids at inlets, and tube length of the TFHE are displayed in the appendix. A propylene glycol (PG)-water ( $30 \%$ by volume), hot water and a PG-water ( $30 \%$ by volume) flow in the outer, inner annuli and innermost tube, respectively. The length of tube of $21.5 \mathrm{~m}$ is inputted to compare with the available data. But it should be noted that the cur- rent model formulation can be predicted at any tube length as long as the flows are in fully developed regions. The comparison confirms a good agreement of the $1 \mathrm{D}$ predictions with the experimental results. It can be observed for the current conditions that temperature cross doesn't occur. However, once inlet temperatures of three fluids are changed to $t_{1, i}=5^{\circ} \mathrm{C}$, $t_{2, i}=40^{\circ} \mathrm{C}$, and $t_{3, i}=15^{\circ} \mathrm{C}$, the temperature cross can be found at the certain position as pointed of in Figure 7 . 


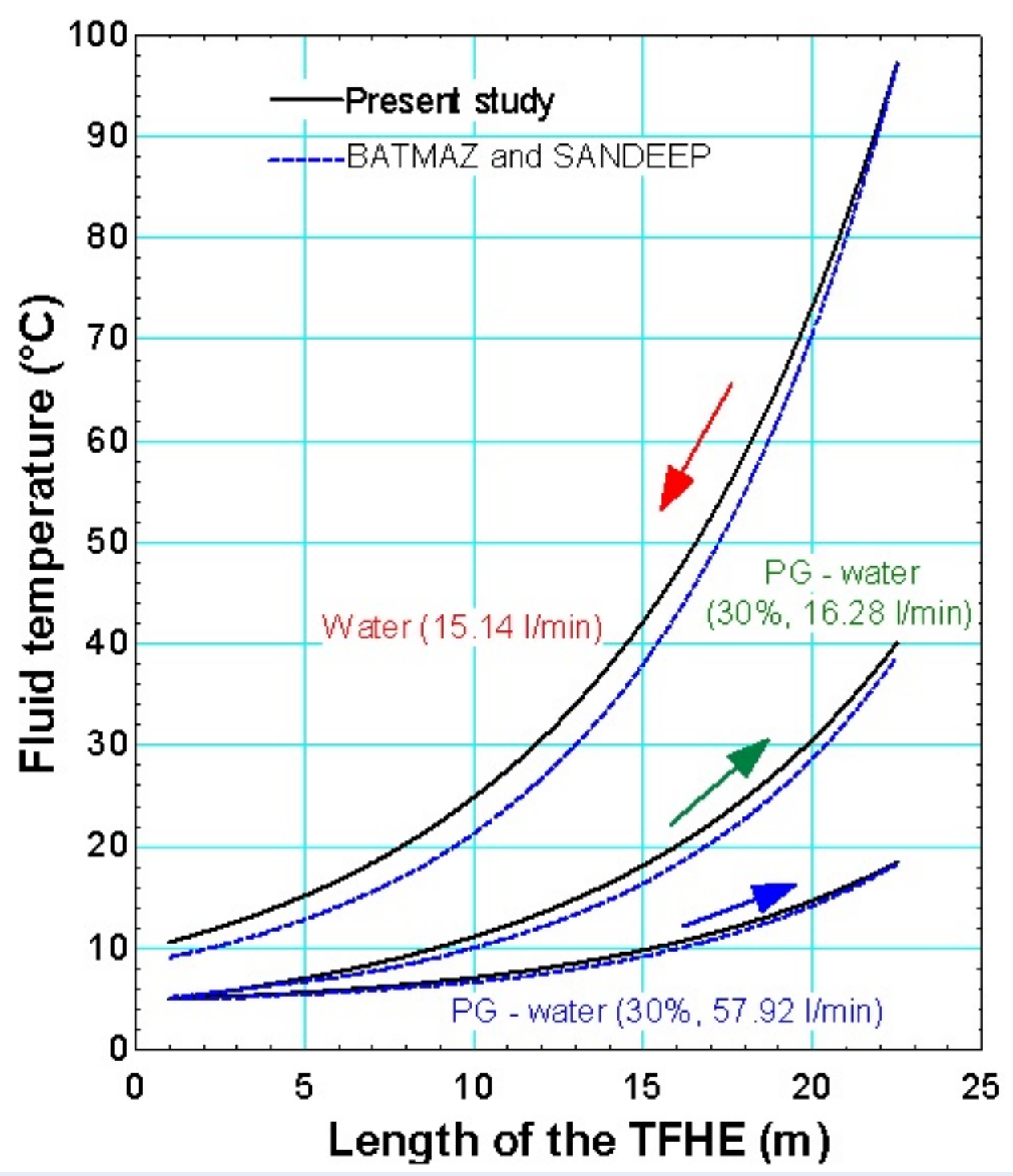

Figure 6: Validation to experimental results ${ }^{9}$

Under these operating conditions, part of TFHE's heat exchanger performed ineffectively. This may be because the heat transfer tube length is too long so the hot fluid (fluid 2) transfers heat to the lowest temperature fluid (fluid 1) resulting in the temperature of fluid 2 which is lower than that of fluid 3. Therefore, one part of the heat transfer surface is useless due to the fact that fluid 3 transfers heat to fluid 2. Only a part of the heat exchanger surface is useful where fluid 2 transfers thermal energy to both fluids 1 and 3 . Without data on the temperature distribution of the fluids inside TFHE, the designer may mistakenly think that the device is working properly since the outlet tem- perature of the hot fluid (fluid 2) decreases and the cold temperature of fluids (fluids 1 and 3 ) increases. Figure 8 showed the TFHE with a reduction of the tube length to $8.5 \mathrm{~m}$, it can be exhibited that there is no temperature cross phenomenon. Under this condition, the device can work, as expected, i.e. the hot fluid transfers heat to the two cold fluids.

\section{CONCLUSIONS}

A compact mathematical model written in the EES environment to determine the temperature distribution along the three-fluid heat exchanger was developed in this study. The temperature distribution pre- 


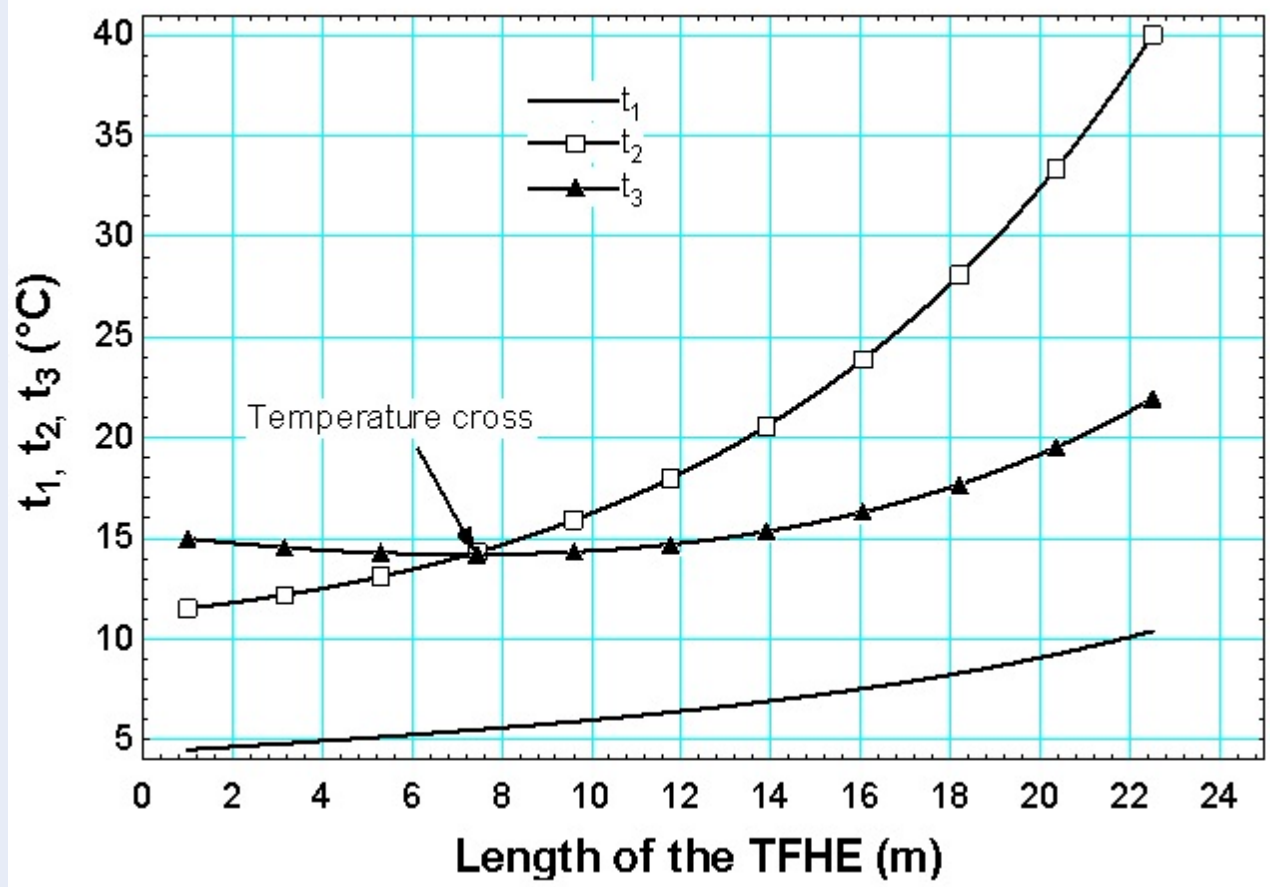

Figure 7: A case with temperature cross occurrence

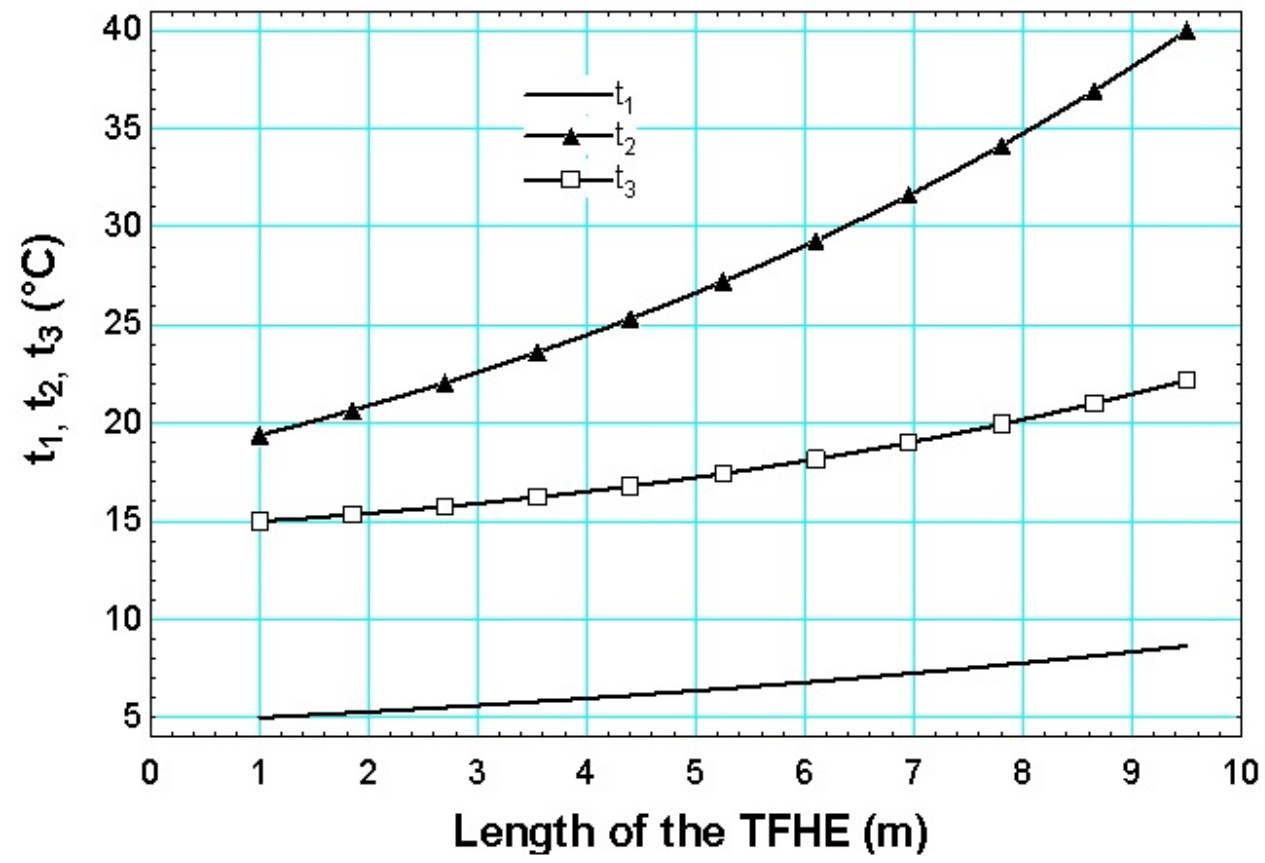

Figure 8: Design modification to avoid temperature cross 
diction is aimed to avoid unwanted temperature cross in heat exchanger design and operation. The calculation program is available for a variety of fluids, fluid temperatures, and geometry of TFHE as well. From the calculation results, the designer can modify parameters of the exchanger and fluid to suppress a temperature cross or a temperature meet. The mathematical model and calculation program are expected to be used for various types of tube surfaces such as roughened tube or finned tube and various fluids in engineering applications.

\section{NOMENCLATURE}

$A$ Heat transfer surface area $\left(\mathrm{m}^{2}\right)$

c Specific heat at constant pressure $\left(\mathrm{J} \mathrm{kg}^{-1} \mathrm{~K}^{-1}\right)$

$d$ Tube diameter $(\mathrm{m})$

$h$ Convection heat-transfer coefficient $\left(\mathrm{W} \mathrm{m}^{-2} \mathrm{~K}^{-1}\right.$ )

$k_{\text {tube }}$ Thermal conductivity of tubing material (W $\mathrm{m}^{-1} \mathrm{~K}^{-1}$ )

$L$ Length of a tube $(\mathrm{m})$

$\dot{m}$ Mass flow rate of a fluid $\left(\mathrm{kg} \mathrm{s}^{-1}\right)$

$P$ dPressure $(\mathrm{Pa})$

$\dot{Q}$ Thermal duty of heat exchanger (W)

$t$ Temperature $\left({ }^{\circ} \mathrm{C}\right)$

th Tube thickness (m)

$U$ Overall heat-transfer coefficient $\left(\mathrm{W} \mathrm{m}^{-2} \mathrm{~K}^{-1}\right)$

Subscripts

1 Fluid 1/Innermost tube

2 Fluid 2/Intermedia tube

3 Fluid 3/Outermost tube

\section{CONFLICT OF INTERESTS}

The author declares that there is no conflict of interests regarding the publication of this paper.

\section{AUTHOR CONTRIBUTION}

Nguyen Minh Phu is in charge of all research content presented in the article.

\section{APPENDIX}

$$
\begin{aligned}
& \text { \$UnitSystem SI Pa J C } \\
& \text { \{inputs } \\
& \text { d_1_i }=\text { d_1_o- } 2^{*} \text { th } \\
& \text { d_1_o=0.0508 [m] } \\
& \text { d_2_i=d_2_o-2 } 2^{\star} \text { th } \\
& \text { d_2_o=0.0635 [m] } \\
& \text { d_3_i }=\text { d_3_o-2*th } \\
& \text { d_3_o=0.0762 [m] } \\
& \text { th=0.00165 [m] } \\
& \text { L=21.5 [m] } \\
& \text { T_1_i }=5[\mathrm{C}] \\
& \text { T_2_i }=97.2[\mathrm{C}] \\
& \text { T_3_i }=5[\mathrm{C}]
\end{aligned}
$$

V_dot_1 $=57.92[1 / \mathrm{min}]$

V_dot_2 $=15.14[1 / \mathrm{min}]$

V_dot_3=16.28 [1/min]

$\mathrm{P}=60^{*}$ convert $(\mathrm{psi}, \mathrm{Pa})$

fluid $1 \$=' P G$ ' $\{$ PG: propylene glycol- water $\}$ fluid $2 \$=$ 'Water'

fluid $3 \$=' P G$ ' $\{$ PG: propylene glycol- water $\}$

$\mathrm{C}=30[\%]$ \{concentration of $\mathrm{PG}$ solution\}

$\mathrm{k} \_$tube $=45[\mathrm{~W} / \mathrm{m}-\mathrm{K}]$

\{lookup fluid properties\}

cp1 $=\mathrm{Cp}$ (fluid $1 \$, T=T \_1 \_i, C=C$ )

rho1=Density(fluid $1 \$, T=T \_1 \_\mathrm{i}, \mathrm{C}=\mathrm{C}$ )

cp2 $=\mathrm{Cp}$ (fluid2 $\$, T=T \_2 \_i, P=P$ )

rho2=Density(fluid2 $\$, T=T \_2 \_i, P=P$ )

cp3 $=\mathrm{Cp}$ (fluid3\$,T=T_3_i,C=C)

rho3=Density(fluid3\$,T=T_3_i,C=C)

\{mass flow rates\}

$\mathrm{m}$ _dot_1=rho $1^{\star} \mathrm{V} \_$dot_ $1^{\star} \operatorname{convert}\left(1 / \mathrm{min}, \mathrm{m}^{\wedge} 3 / \mathrm{s}\right)$

$\mathrm{m}$ _dot_2=rho $2^{\star} \mathrm{V} \_$dot_2 $2^{*} \operatorname{convert}\left(1 / \mathrm{min}, \mathrm{m}^{\wedge} 3 / \mathrm{s}\right)$

m_dot_3 $=$ rho $3^{\star} \mathrm{V} \_$dot_ $3{ }^{*} \operatorname{convert}\left(1 / \mathrm{min}, \mathrm{m}^{\wedge} 3 / \mathrm{s}\right)$

\{lookup heat transfer coefficients\}

call PipeFlow(fluid1\$,T_1_i,C,m_dot_1,d_1_i,L,0:h_T_1,

h_H_1,DELTAP_1, Nusselt_T_1, f_1, Re_1)

call AnnularFlow(fluid2\$,T_2_i,P,m_dot_2,d_1_o/2,d_2_i/2,L,C

h_H_2,DELTAP_2, Nusselt_T_2,f_2, Re_2)

call AnnularFlow(fluid3\$,T_3_i,C,m_dot_3,d_2_o/2,d_3_i/2,L,

h_H_3 ,DELTAP_3, Nusselt_T_3, f_3, Re_3) \{calcu-

late conductance $\}$

UA_21 $=1 /\left(1 /\left(h \_H \_1^{\star} \mathrm{A} \_1\right)+\ln \left(\mathrm{d} \_1 \_\mathrm{o} / \mathrm{d} \_1 \_\mathrm{i}\right) /\left(2^{\star} \mathrm{pi}^{\star} \mathrm{k} \_t u b \mathrm{e}^{\star} \mathrm{L}\right)+\right.$

UA_23 $=1 /\left(1 /\left(h \_H \_2^{\star} A \_3\right)+\ln (\right.$ d_2_o/d_2_i $) /\left(2^{\star} \mathrm{pi}^{\star} \mathrm{k} \_t u b \mathrm{e}^{\star} \mathrm{L}\right)+$

\{surface areas\}

A_1 $=$ pi $^{*}$ d_1_i $i^{*} \mathrm{~L}$

A_2 $=$ pi $^{\star}$ d_1_o ${ }^{\star} \mathrm{L}$

A_3 $=$ pi $^{\star}$ d_2_i $i^{\star} \mathrm{L}$

A_4=pi ${ }^{\star}$ d_2_o ${ }^{\star} \mathrm{L}$

\{temperature gradients\}

$\mathrm{dT} 2 \mathrm{dx}=\quad-\mathrm{UA} \_21^{*}\left(\mathrm{~T} \_2-\mathrm{T} \_1\right) /\left(\mathrm{L}^{*} \mathrm{~m} \_\mathrm{dot} \_2^{*} \mathrm{cp} 2\right)$

-UA_23*(T_2-T_3)/(L*m_dot_2*cp2)

$\mathrm{dT} 1 \mathrm{dx}=\mathrm{UA} \_21^{*}\left(\mathrm{~T} \_2-\mathrm{T} \_1\right) /\left(\mathrm{L}^{*} \mathrm{~m} \_\mathrm{dot} \_1^{*} \mathrm{cp} 1\right)$

$\mathrm{dT} 3 \mathrm{dx}=\mathrm{UA} \_23^{*}\left(\mathrm{~T} \_2-\mathrm{T} \_3\right) /\left(\mathrm{L}^{*} \mathrm{~m} \_\mathrm{dot} \_3^{*} \mathrm{cp} 3\right)$

\{numerical integration\}

$\mathrm{n}=10$

DELTAx $=\mathrm{L} / \mathrm{n}$

\$integralTable x:DELTAx,T_1,T_2,T_3,x_revert

T_2=T_2_i+integral(dT2dx,x,0,L,DELTAx $)\left\{! \mathrm{T} \_2 \_i\right.$

known\}

T_1=T_1_o-integral(dT1dx,x,0,L,DELTAx) $\{$ ! T_1_o

unknown

T_3=T_3_o-integral(dT3dx,x,0,L,DELTAx) \{! T_3_o

unknown\}

\{errors

err_1=abs(T_1-T_1_i) 


\author{
err_3=abs(T_3-T_3_i) \\ err=err_1+err_3 \\ \{heat transfer rates\} \\ Q_dot_1=cp $1^{*}$ m_dot_1 ${ }^{*}\left(\mathrm{~T} \_1\right.$-o-T_1_i $)$ \\ Q_dot_2 $=$ cp $2^{*}$ m_dot_2*(T_2_i-T_2_o $)$ \\ Q_dot_3 $=$ cp $3{ }^{*} \mathrm{~m} \_$dot $\_3{ }^{*}\left(\mathrm{~T} \_3 \_0-\mathrm{T} \_3 \_\mathrm{i}\right)$ \\ Q_dot_2=Q_dot_1+Q_dot_3 \\ \{change $\mathrm{x}$-axis scale\} \\ x_revert $=(\mathrm{L}-\mathrm{x})+1$

\section{REFERENCES}

1. Phu NM, Trinh NTM. Modelling and experimental validation for off-design performance of the helical heat exchanger with LMTD correction taken into account. Journal of Mechanical Science and Technology. 2016;30(7):3357-3364. Available from: https://doi.org/10.1007/s12206-016-0645-0.

2. Phu NM, Hap NV. Influence of inlet water temperature on heat transfer and pressure drop of dehumidifying air coil using analytical and experimental methods. Case Studies in Thermal Engineering. 2020;18:100581. Available from: https: //doi.org/10.1016/j.csite.2019.100581.

3. Phu NM, Sik LG. Characteristics of the Water Pressure Drop Considering Heat Transfer in the Evaporator and Condenser of a Water Chiller. Transactions of the Korean Society of Mechanical Engineers B. 2011;35(12):1293-1300. Available from: http://doi.org/10.3795/KSME-B.2011.35.12.1293.

4. Ngo TT, Phu NM. Computational fluid dynamics analysis of the heat transfer and pressure drop of solar air heater with coniccurve profile ribs. Journal Thermal Analysis and Calorimetry. 2020;139:3235-3246. Available from: https://doi.org/10.1007/ s10973-019-08709-4.

5. Phu NM, Tuyen V, Ngo TT. Augmented heat transfer and friction investigations in solar air heater artificially roughened with metal shavings. Journal of Mechanical Science and Technology. 2019;33(7):3521-3529. Available from: https://doi org/10.1007/s12206-019-0646-x.

6. Mohapatra T, Padhi BN, Sahoo SS. Analytical investigation and performance optimization of a three fluid heat exchanger with helical coil insertion for simultaneous space heating and water heating. Heat Mass Transfer. 2019;55:1723-1740. Available from: https://doi.org/10.1007/s00231-018-02545-2.

7. Tuyen V, Hap NV, Phu NM. Thermal-hydraulic characteristics and optimization of a liquid-to-suction triple-tube heat exchanger. Case Studies in Thermal Engineering. 2020;p. 100635. Available from: https://doi.org/10.1016/j.csite.2020. 100635.

8. Thulukkanam K. Heat exchanger design handbook, CRC press. 2013;p. 54-55. Available from: https://doi.org/10.1201/b14877.

9. Batmaz E, Sandeep K. Overall Heat Transfer Coefficients And Axial Temperature Distribution In A Triple Tube Heat Exchanger. Journal of Food Process Engineering, Volume. 2008;31:260-279.

10. Batmaz E, Sandeep KP. Calculation of overall heat transfer coefficients in a triple tube heat exchanger. Heat and Mass Transfer, Volume. 2005;41:271-279. Available from: https: //doi.org/10.1007/s00231-004-0546-0.

11. Gomaa A, Halim MA, Elsaid AM. Experimental and numerical investigations of a triple concentric-tube heat exchanger. Applied Thermal Engineering, Volume. 2016;99:1303-1315. Available from: https://doi.org/10.1016/j.applthermaleng.2015. 12.053 .

12. F-chart software, Engineering Equation Solver. 2013;

13. Nellis G, Klein S. Heat Transfer. Cambridge university press. 2009;Available from: https://doi.org/10.1017/ CBO9780511841606.

14. Phu NM, Sik LG. Characteristics of pressure and force considering friction in a closed cylinder with a holed piston. Journal Mechanical Science and Technology. 2014;28:2409-2415. Available from: https://doi.org/10.1007/s12206-014-0533-4. 


\title{
Một chương trình EES nhỏ gọn để dự đoán trường nhiệt độ dọc trục trong thiết bị trao đổi nhiệt ba lưu chất
}

\author{
Nguyễn Minh Phú ${ }^{1,2}$,*
}

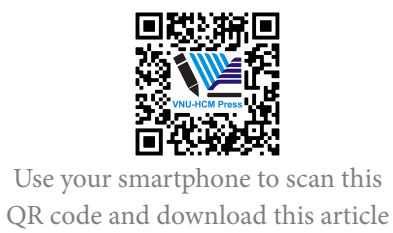

${ }^{1}$ Khoa Cơ khí, Trường Đai học Bách khoa, Thành phố Hồ Chí Minh, Việt Nam

${ }^{2}$ Đại học Quốc gia Thành phố Hồ Chí Minh, Việt Nam

Liên hệ

Nguyễn Minh Phú, Khoa Cơ khí, Trường Đại học Bách khoa, Thành phố Hồ Chí Minh, Việt Nam

Đại học Quốc gia Thành phố Hồ Chí Minh, Việt Nam

Email: nmphu@hcmut.edu.vn

Lịch sử

- Ngày nhận: 17-04-2020

- Ngày chấp nhận: 26-10-2020

- Ngày đăng: 03-11-2020

DOI : 10.32508/stdjet.v3i3.736

\section{Check for updates}

\section{Bản quyền}

๑ ĐHQG Tp.HCM. Đây là bài báo công bố mở được phát hành theo các điều khoản của the Creative Commons Attribution 4.0 International license.

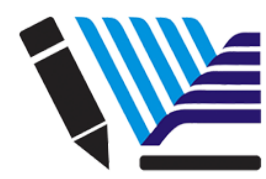

VNU-HCM Press

\begin{abstract}
TÓM TẮT
Trong bài báo này, một mô hình toán đơn giản được trình bày để dự đoán trường nhiệt độ dọc trục của các lưu chất trong một thiết bị trao đổi nhiệt ba ống đônng tâm. Mô hình được thành lập trền cơ sở của phương trình cần bằng nhiệt, phương trình truyền nhiệt, gradient nhiệt độ, và phương pháp độ chênh nhiệt độ trung bình logarit (LMTD). Thiết bị trao đổi nhiệt ba ống là một giải pháp thay thế để nâng cao truyền nhiệt và giảm tổn thất áp suất lưu chất làm việc. Phương pháp thể tích kiểm soát được sử dụng để xác định phân bố nhiệt độ dọc trục bằng cách dùng phân mêm EES (Engineering Equation Solver). Sự kết hợp giữa phương pháp và EES chứng tỏ hội tụ nhanh và sai số nhỏ đáng kể. Chương trình EES chỉ gồm khoảng hai mươi dòng chính đã chứng tỏ tính đơn giản và gọn nhẹ. Các kết quả tính toán được so sánh với các kết quả thực nghiệm để xác nhận độ chính xác. Mục tiêu của nghiên cứu là để tránh chéo nhiệt độ, hiện tượng mà rất thường xảy ra trong các thiết bị trao đổi nhiệt ba lưu chất. Chéo nhiệt độ dẫn đến bề mặt truyền nhiệt không hiệu quả trong thiết bị trao đổi nhiệt. Từ đó người thiết kế hoặc vận hành có thể điểu chỉnh các thông số thiết kế, chẳng hạn thông số hình học của bộ trao đổi nhiệt, các nhiệt độ hoặc lưu lượng các lưu chất, để chéo nhiệt độ không xảy ra. Kết quả tính toán cho một trường hợp chỉ ra rằng ở ống dài 21,5 m, chéo nhiệt độ xuất hiện giữa lưu chất nóng và lưu chất trung gian ở một vị trí xác định. Ống ngắn $8,5 \mathrm{~m}$ mang lại kết quả mong muốn. Chương trình EES và trình tự tính toán chi tiết được mô tả trong nghiên cứu hiện tại. Nghiên cứu này có thể áp dụng cho đa dạng các kiểu bề mặt truyền nhiệt (các bề mặt nhám hoặc làm cánh) và các loại lưu chất (khí, lỏng, hoặc các hỗn hợp). Hơn nữa, tối ưu hóa hiệu suất nhiệt thủy lực có thể được mở rộng cho thiết bị trao đổi nhiệt ba lưu chất.
\end{abstract}

Từ khoá: Chéo nhiệt độ, ba ống, ba lưu chất, trường nhiệt độ, EES, thiết bị trao đổi nhiệt
Trích dẫn bài báo này: Phú N M. Một chương trình EES nhỏ gọn để dự đoán trường nhiệt độ dọc trục trong thiết bị trao đổi nhiệt ba lưu chất. Sci. Tech. Dev. J. - Eng. Tech.; 3(3):452-460. 